\section{Rheumatoid meningitis: report of two cases}

\author{
CARLOS GUEVARA ${ }^{1, a}$, EDUARDO VILLA ${ }^{1, b}$, \\ RENÉ NÚÑEZ ${ }^{2}$, JOSÉ DE GRAZIA²
}

\begin{abstract}
Rheumatoid meningitis ( $R M)$ is a rare complication of rheumatoid arthritis (RA). RM mimics many other conditions such as subdural empyema, unsteady gait, focal brain dysfunction, stroke, relapsing-remitting motor signs, headache, neuropsychiatric disorders, seizures, parkinsonism, and meningeal tumors. RM is considered a disease with poor prognosis. However, cases reported in the last decade show a good outcome. We report two cases with a favorable outcome. A 48-year-old man with a three-year history of RA admitted for headache, sensory disturbances, and speech difficulties. Brain magnetic resonance imaging (MRI) showed a left parietal subdural laminar lesion with restricted diffusion and a small left superior frontal acute infarction. A subdural empyema was originally suspected, and antimicrobials were prescribed. A follow-up MRI did not show progression of the subdural lesion and the patient was discharged 14 days after admission without focal deficits. A 44-year-old female patient with two years of seronegative RA was admitted for severe headache, confusion, nausea and vomiting. Brain MRI showed subtle supra and infratentorial leptomeningeal involvement and a left cerebellar acute infarct. A meningoencephalitis due to etanercept was initially thought and treated with dexamethasone. The patient was discharged but had to be admitted again and a new MRI showed a progression of the leptomeningeal involvement. She worsened and required endotracheal intubation. Cyclophosphamide was started and the patient became asymptomatic three months later. We propose that treatment should not be delayed waiting a biopsy when a diagnosis of RM is made and after a cerebrospinal fluid infection has been ruled out.
\end{abstract}

(Rev Med Chile 2021; 149: 295-303)

Key words: Arthritis, Rheumatoid; Therapeutics; Meningitis, Aseptic.

\section{Meningitis reumatoide. Informe de dos casos}

Meningitis reumatoide es una complicación rara de la artritis reumatoide. Esta enfermedad simula varias afecciones neurológicas, como empiema subdural, marcha inestable, accidente cerebrovascular, signos motores recurrentes-remitentes, cefalea, trastornos neuropsiquiátricos, convulsiones, parkinsonismo y tumores de las meninges. Es considerada de mal pronóstico, sin embargo, casos en la última década muestran lo contrario. Informamos dos casos con buen pronóstico. Un hombre de 48 años con tres años de artritis reumatoide ingresado por cefalea, trastornos sensoriales y dificultades del habla. La resonancia magnética (RM) cerebral mostró una lesión laminar subdural parietal izquierda y un pequeño infarto agudo frontal izquierdo. Inicialmente se sospechó un empiema subdural
Department of Neurology and Neurosurgery, Faculty of Medicine, Hospital Clínico Universidad de Chile. Universidad de Chile. Santiago, Chile.

${ }^{2}$ Department of Radiology, Faculty of Medicine, Hospital Clínico Universidad de Chile. Universidad de Chile. Santiago, Chile. ${ }^{\mathrm{a} P h D}$.

${ }^{\mathrm{b}}$ Estudiante de Medicina.

Recibido el 18 de abril de 2020, aceptado el 9 de diciembre de 2020 .

The authors received no financial support for the research, authorship, and/or publication of this article.

The authors have no conflict of interest to declare.

Author contributions. CG conception, organization, and execution, review and critique. EV: conception, organization, and execution, review and critique. RN: conception, organization, and execution, review and critique. JdG: conception, organization, and execution, review and critique

Corresponding author. Carlos Guevara. Address: Amapolas 1475, apt 601. Providencia. Santiago, Chile. neurocrs@gmail.com 
y se trató con antibióticos. Una RM de control no mostró progresión de la lesión subdural y el paciente fue dado de alta 14 días después del ingreso sin déficit focales. Una mujer de 44 años con dos años de artritis reumatoide seronegativa fue ingresada por cefalea, confusión náuseas y vómitos. La RM cerebral mostró un compromiso sutil leptomeningeo supra e infratentorial y un infarto agudo cerebeloso izquierdo. Inicialmente se consideró una meningoencefalitis debido a etanercept y se trató con dexametasona. Fue dada de alta pero debió ingresar al hospital nuevamente y una nueva RM mostró progresión del compromiso leptomeningeo. Ella se agravó y requirió intubación endotraqueal. Se inició ciclofosfamida y la paciente se hizo asintomática tres meses después. Proponemos que el tratamiento no debe retrasarse esperando una biopsia de meninges cuando se realiza un diagnóstico clínico de meningitis reumatoide, después de descartar infecciones meningeas.

Palabras clave: Artritis Reumatoide; Meningitis Aséptica; Terapéutica.

$\mathrm{R}$ heumatoid meningitis (RM) is a rare complication of rheumatoid arthritis (RA). Neurological manifestations vary widely, and diagnosis remains a challenge because RM mimics many other conditions; hence, RM is another 'great mimicker' in neurology. This entity can present and/or has been misdiagnosed as subdural empyema ${ }^{1}$, subdural haematoma ${ }^{2}$, unsteady gait and falls ${ }^{3}$, sudden-onset focal brain dysfunction and/or stroke $e^{4-10}$, relapsing-remitting signs ${ }^{11}$, headache ${ }^{5,12-14}$, acute neuropsychiatric disorders and confusion ${ }^{8,15-19}$, seizures ${ }^{13,20-22}$, epilepsy ${ }^{23,24}$, parkinsonism ${ }^{25,26}$, and granuloma of the meninges ${ }^{27}$.

$\mathrm{RM}$ is believed to have a poor prognosis; however, the reported cases in the last decade and two new cases reported in this article demonstrate that RM has a good outcome.

\section{Clinical Cases}

\section{Case 1}

In 2015, a 48-year-old man was diagnosed with RA based on polyarthralgia, including knees and hands with synovitis of the distal interphalangeal joints. Rheumatoid factor (RF) was 829 UI/ $\mathrm{ml}$ (normal value $<20 \mathrm{UI} / \mathrm{ml}$ ); anti-cyclic citrullinated peptide antibodies (anti-CCP) were 300 $\mathrm{U} / \mathrm{ml}$ (normal value $<7 \mathrm{U} / \mathrm{ml}$ ). Tenosynovitis of the tibialis anterior was diagnosed by ultrasound. $\mathrm{He}$ was treated with prednisone $5 \mathrm{mg}$ /day and weekly methotrexate (7.5 mg). In 2018, he had oppressive headache in the left parietal region with nausea, and transient sensory disturbances in the right face and right upper extremity every day. Then, on the eleventh day, he developed inconsistent production of speech sounds. He was admitted to the emergency department. There was no fever, pain in any joint, rashes, nail changes or lymphadenopathy. There were no other neurological signs. He had an elevated $\mathrm{C}$-reactive protein (CRP) level of $34 \mathrm{mg} / \mathrm{dl}$ (normal $<5 \mathrm{mg} / \mathrm{dl}$ ) and erythrocyte sedimentation rate (ESR) of $37 \mathrm{~mm} /$ hour (normal $<20 \mathrm{~mm} /$ hour). $\mathrm{RF}$ was $>1200$ $\mathrm{UI} / \mathrm{ml}$ and antinuclear antibody (ANA) testing was positive (1:80). Complete blood cell count, calcium, magnesium, and phosphorus levels, liver function tests, urinalysis, thyroid-stimulating hormone, antithyroglobulin, antithyroperoxidase antibody, cortisol, vitamin B12 levels and toxicology tests were unremarkable. A human immunodeficiency virus test and rapid plasma reagin were negative. The chest $\mathrm{x}$-ray was normal and abdominal ultrasound showed signs of gallstones. Brain magnetic resonance imaging (MRI) showed a left parietal subdural laminar lesion with ipsilateral pachymeningeal and leptomeningeal involvements. There was also a small left superior frontal acute infarct (Figure 1). Brain computed tomography (CT) angiography did not show signs of vasculitis. Cerebrospinal fluid (CSF) analysis was unremarkable, including testing for infectious encephalitis ( $E$. coli $\mathrm{K} 1, H$. influenzae, L. monocytogenes, $N$. meningitidis, $S$. agalactiae, S. pneumoniae, Cytomegalovirus, Enterovirus, Herpes simplex 1 and 2, Herpes 6, Parechovirus, Varicella zoster, Cryptococcus neoformans, Mycobacterium tuberculosis and Epstein-Barr virus). A subdural empyema was diagnosed and he was 


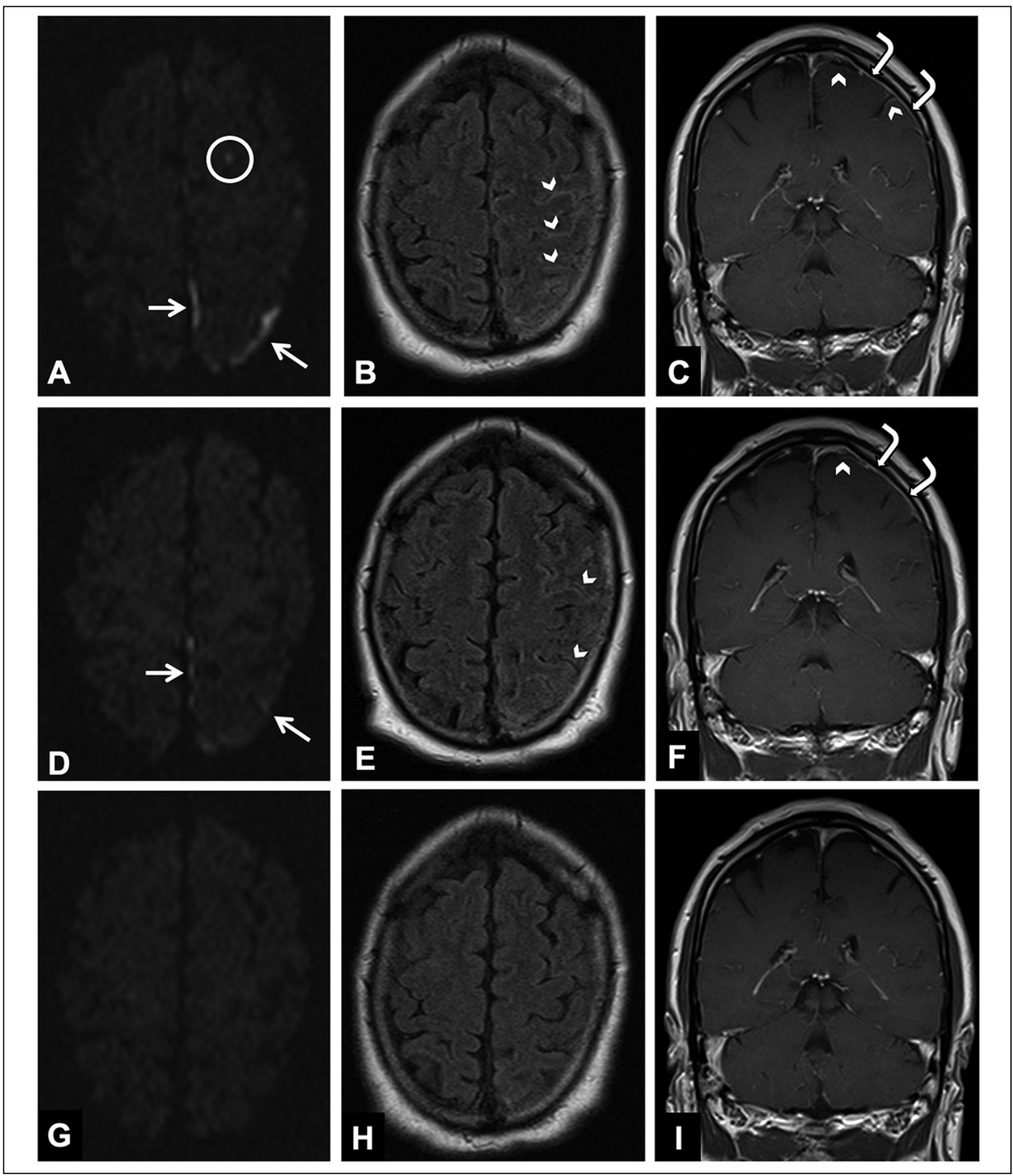

Figure 1. Initial Brain MRI (A, B and C). DWI (A) shows a left parietal subdural laminar lesion with restricted diffusion (straight arrows) and a small left superior frontal acute infarct (circle); the ADC map is not shown. FLAIR (B) shows hyperintensity on cortical sulci of the left frontal and parietal lobes (arrowheads). T1 with Gadolinium in a coronal slice (C) shows subtle left parietal leptomeningeal enhancement (arrowheads) and subtle pachymeningeal thickening (curved arrows). Follow-up brain MRI, performed 2 months later (D, E and F). DWI (D) shows partial regression of the left parietal subdural laminar lesion (straight arrows). On FLAIR (E) and coronal T1 with Gadolinium (F) there is also partial regression of the left fronto-parietal leptomeningeal involvement (arrowheads) and persistence of the subtle left parietal pachymeningeal thickening (curved arrows). Follow-up brain MRI, performed 1 year later $(\mathbf{G}, \mathbf{H}$ and $\mathbf{I})$. The pathological findings have resolved. DWI (G), FLAIR (H) and coronal T1 with Gadolinium are normal. 
started on broad-spectrum antibiotics for 14 days. Follow-up MRI performed did not show progression of the subdural lesion; thus, neurosurgical intervention was not required. Prednisone at a dosage of $10 \mathrm{mg} /$ day was resumed. The patient was discharged on day 14 without neurological deficits. At the two-month follow-up visit, brain MRI showed partial regression of the alterations (Figure 1), and at the one-year follow-up the brain MRI was normal (Figure 1). In 2020 and over the course of 2 years the patient has remained asymptomatic.

\section{Case 2}

A 35-year-old female patient started with small and large joints polyarthralgia; RA was diagnosed with a seronegative study. It progressed refractory to conventional disease-modifying antirheumatic drugs (DMARDs). Adalimumab was started but persisted symptomatic. It was changed to etanercept $50 \mathrm{mg} /$ week, prednisone $20 \mathrm{mg} /$ day and weekly dose of methotrexate (7.5 $\mathrm{mg}$ ), achieving remission of arthritis. In 2019, at the age of 44 years, she was admitted for a severe headache, confusion, vomiting and fever $\left(38^{\circ} \mathrm{C}\right)$.

Table 1. Patient 2. Diagnostic testing

\begin{tabular}{|c|c|c|}
\hline Test & Obtained value & Normal value \\
\hline Rheumatoid factor (UI/mL) & $<10$ & $<10$ \\
\hline \multicolumn{3}{|l|}{ Complement (mg/dL) } \\
\hline C3 & 128 & $70-176$ \\
\hline $\mathrm{C} 4$ & 19.4 & $16.3-44.7$ \\
\hline Anti dsDNA IgG ELISA (UI) & 14.6 & $<35$ \\
\hline Anti-Nuclear Antibodies ${ }^{1}$ & $\begin{array}{l}\text { 1/160 (nuclear homogenous and } \\
\text { speckled pattern) }\end{array}$ & $<1 / 80$ \\
\hline \multicolumn{3}{|l|}{ Immunoglobulins (mg/dL) } \\
\hline $\lg A$ & 202 & $70-312$ \\
\hline $\lg M$ & 24.5 & $56-352$ \\
\hline $\lg G$ & 745 & $639-1349$ \\
\hline $\operatorname{lgG} 1$ & 414 & $405-1011$ \\
\hline $\lg G 2$ & 154 & $169-786$ \\
\hline $\lg G 3$ & 20.5 & $11-85$ \\
\hline $\lg G 4$ & 16.7 & $3-201$ \\
\hline Anti-PR3 (U/mL) & 1.8 & $<10$ \\
\hline \multicolumn{3}{|l|}{ ENA (UA/mL) } \\
\hline SSA/Ro & 10.7 & $<12$ \\
\hline SSB/La & $<3$ & $<12$ \\
\hline Sm & $<3$ & $<12$ \\
\hline Sm/RNP & $<3$ & $<12$ \\
\hline Scl-70 & $<3$ & $<12$ \\
\hline Jo-1 & $<3$ & $<12$ \\
\hline Vitamin B12 (pg/mL) & 542 & $239-931$ \\
\hline Beta 2 GP1 IgM (UA/mL) & 0.5 & $<12$ \\
\hline Beta 2 GP1 lgG (UA/mL) & 1.5 & $<12$ \\
\hline Anticardiolipin IgM (MPLU/mL) & 0.4 & $<12$ \\
\hline Anticardiolipin IgG (GPLU/mL) & 1.3 & $<12$ \\
\hline \multicolumn{3}{|l|}{ Serum free light chains $(\mathrm{mg} / \mathrm{dL})^{2}$} \\
\hline Kappa & 9.02 & $3.3-19.4$ \\
\hline Lambda & 13.45 & $5.7-26.3$ \\
\hline
\end{tabular}

${ }^{1}$ ANA. ${ }^{2}$ After discharge, on February of 2020. 


\section{Table 1. Cases of rheumatoid meningitis reported in the last decade}

DD: disease duration/years (y); LS: long-standing; P: at RA presentation.

RA treatment. A: aurofin; Pr: prednisone; Pl: plaquenil; M: methotrexate; Pn: prednisolone; Ad: adalimumab; S: sulfasalazine; L: leflunomide; C: chloroquine; E: etanercept; Cs: corticosteroids; I: infliximab.

RM clinical picture. Abs: subdural empyema; F+Gi unsteady gait and falls; Str: sudden-onset focal brain dysfunction and/or stroke; Rr: relapsing-remitting and progressive motor signs; $\mathrm{H}$ : headache; Cs: acute neuropsychiatric disorders and confusion; Rm: relapsing meningoencephalitis; Sz: seizures; Epc: epilepsia partialis continua; Msz: myoclonic seizures; Park: parkinsonism; Pcg: isolated plasma cell granuloma of the meninges; CSDH: chronic subdural haematoma.

Activity. S: synovitis; F: fever; RF: rheumatoid factor (normal value < $20 \mathrm{UI} /$; or < 1: 80); CCP: anti-cyclic citrullinated peptide (normal value $<7 \mathrm{u} / \mathrm{ml}$ ); CRP: C-reactive protein (normal value $<5 \mathrm{mg} / \mathrm{L}$ ); ESR: erythrocyte sedimentation rate (normal value: $<20 \mathrm{~mm} / \mathrm{h}$ ); H: high; $\mathrm{N}$ : normal.

CSF: cerebrospinal fluid; WCC: white cell count (normal< 5/mm); Pr: protein level (normal 0.15-0.4g/L)

MRI findings pattern: Type 1: pure pachymeningeal involvement; Type 2: pure leptomeningeal involvement; Type 3: pure parenchymal involvement; Type 4: mixed pattern; +: extra-axial lesion with restricted diffusion; f: focal involvement; d: diffuse involvement (see Table 2).

Microscopy pathology: N: nodules; V: vasculitis; Mi: meningeal inflammation.

Treatment: Mp: Methylprednisolone; Dx: dexamethasone;

w: week(s); d: days

?: not reported; +: present; -: absent; np: not performed.

Table 2. Brain MRI patterns

\begin{tabular}{|lll|}
\hline \multicolumn{2}{|c|}{ Pattern } & Findings \\
\hline Type 1 & Pure pachymeningeal involvement & Dural thickening \\
Type 2 & Pure leptomeningeal involvement & Sulcal FLAIR hyperintensity and/or Gadolinium enhancement \\
Type 3 & Pure parenchymal involvement & $\begin{array}{l}\text { Parenchymal FLAIR hyperintensity and/or restricted diffusion and/or } \\
\text { gadolinium enhancement }\end{array}$ \\
Type 4 & Mixed & Any combination of the type 1, 2 and 3 \\
\hline
\end{tabular}

Table 2. Associated features, useful in the differential diagnosis: Plus $(+)$ : Extra-axial lesion with restricted diffusion. Focal involvement (f); Diffuse involvement $(\mathrm{d})$. The case 1 corresponds to a type $4 \mathrm{f}+$ pattern, and the case 2 corresponds to a type $4 \mathrm{f}$ pattern.

She did not have signs of active RA. Serological tests showed CRP level of $34 \mathrm{mg} / \mathrm{dl}$ and an ESR of $58 \mathrm{~mm} / \mathrm{h}$. An extensive blood testing, urinalysis (as in patient 1) and blood tests for rheumatology conditions were unremarkable. Marker for IgG4-related disease (IgG4-RD) was negative. Serum screening for malignancies was also negative (Table 1). Abdominal, pelvic and thoracic CT was normal.

Brain MRI showed bilateral parietal leptomeningeal involvement and a small right frontal acute infarct (Figure 2). CSF analysis showed a white blood cell count of $8 / \mathrm{mm}^{3}$, protein of 0.71 $\mathrm{g} / \mathrm{L}$, and glucose of $60 \mathrm{mg} / \mathrm{dl}$. Tests for metabolic encephalopathies were negative, and testing for CSF infectious encephalitis was unremarkable (as performed in case 1). Electroencephalography (EEG) showed theta slowness, without irritating activity. Meningoencephalitis due to etanercept was suspected ${ }^{28}$, and empiric treatment with 10 mg of dexamethasone every 8 hours for 5 days was started. The patient became asymptomatic and returned home. Two weeks later, a new episode of severe headache started. Brain MRI showed progression of leptomeningeal involvement and a small cerebellar acute infarct (Figure 2). Brain 

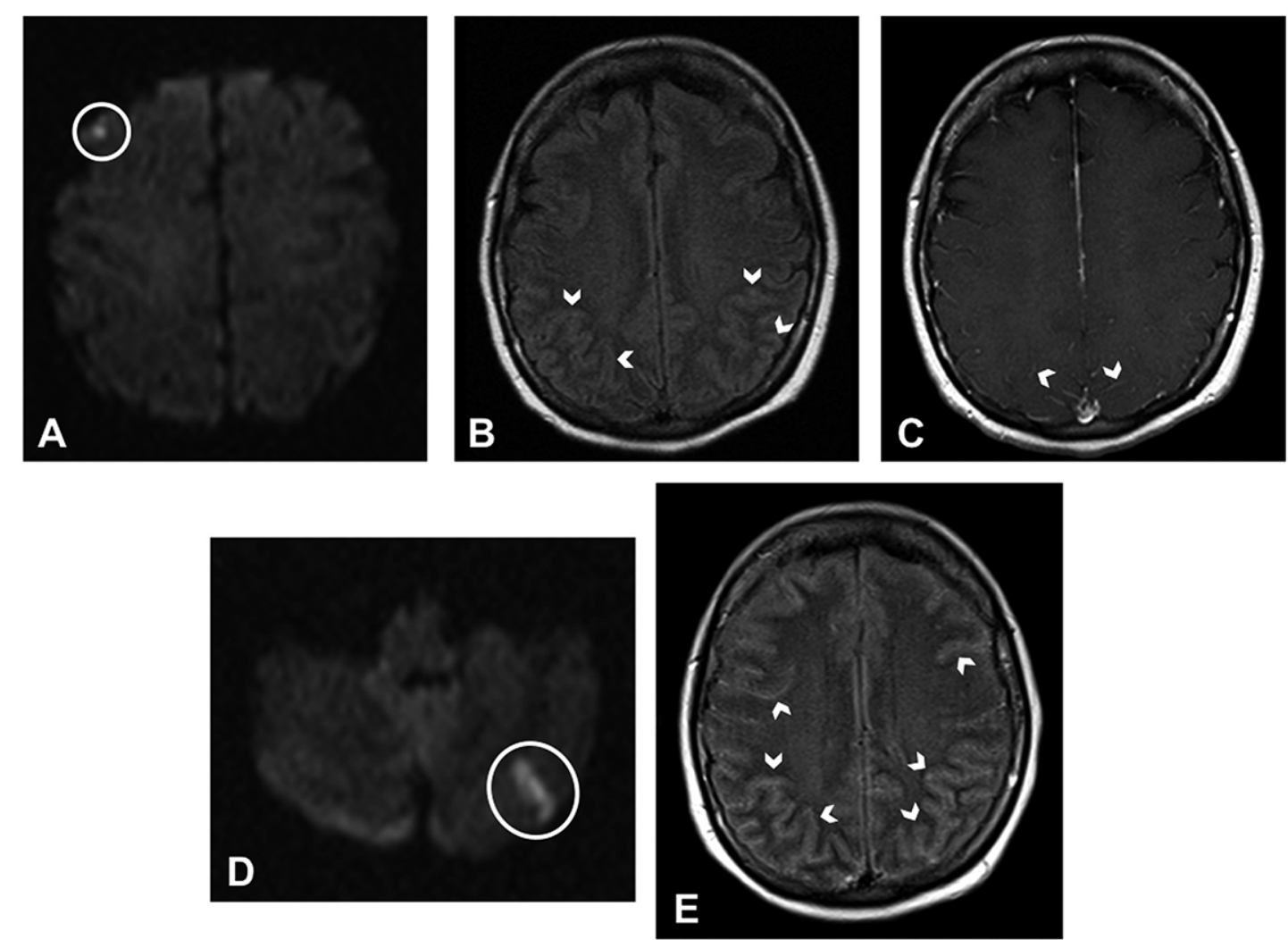

Figure 2. Initial brain MRI (A, B and C). DWI (A) shows a small right frontal acute infarct (circle); the ADC map is not shown. FLAIR (B) shows subtle hyperintensity on the cortical sulci of the parietal lobes (arrowheads). T1-weighted imaging with gadolinium $(\mathbf{C})$ shows subtle bilateral parietal leptomeningeal enhancement (arrowheads). Follow-up brain MRI without gadolinium performed 2 weeks later (D and E). DWI (D) shows a left cerebellar acute infarct (circle). On FLAIR (E), there is marked progression of supratentorial leptomeningeal involvement (arrowheads).

CT angiography did not show signs of vasculitis. CSF analysis showed normal white cells, glucose of $43 \mathrm{mg} / \mathrm{dl}$ and proteins of $1.74 \mathrm{~g} / \mathrm{L}$. Another viral and bacterial CSF studies were unremarkable. A panel for autoimmune encephalitis was negative (including antibodies against the N-methyl-D-aspartate [NMDA]). One day later, the patient developed deterioration of consciousness and required endotracheal intubation. EEG did not support a non-convulsive status. Intravenous (I.V.) methylprednisolone one-gram daily for 5 days and I.V. immunoglobulin at $2 \mathrm{~g} / \mathrm{kg}$ in two days were given. She recovered consciousness and was extubated. One week later, she had mild left cerebellar dysmetria and was discharged home. She started immunosuppressive treatment with cyclophosphamide at $900 \mathrm{mg} / \mathrm{monthly}$. Three months later, she was fully asymptomatic. The patient was subsequently switched to rituximab $1000 \mathrm{mg}$ IV every six months. Over the course of 2 years she has remained asymptomatic.

\section{Ethics statement}

The study was conducted according to International Standards of Good Clinical Practice (ICH guidelines and the Declaration of Helsinki). The project was approved by the local Research Ethics Committees of Universidad de Chile Hospital, Santiago, Chile. Both subjects gave written informed consent for the publication of this case report in accordance with the Declaration of Helsinki. 


\section{Discussion}

$\mathrm{RM}$ is a rare complication of RA. In our two cases, the patients had well-controlled RA. In case 1, a subdural empyema was suspected as the initial diagnosis. Clinical cases of RM have been reported in which initially a brain abscess or a subdural collection were diagnosed ${ }^{1,21,29}$. In case 2 , an unusual case of meningoencephalitis due to etanercept was initially suspected and this led to misdiagnosis ${ }^{28}$. In these two cases, a meningeal biopsy was not performed because of the rapid improvement and the reassessment of the MRI findings; in particular, asymmetric focal meningeal involvement was helpful for the diagnosis of RM. Several cases have been diagnosed without biopsy and successfully treated ${ }^{4,5,14,16,24}$, in a recent review 8 out of 39 cases were not confirmed by biopsy ${ }^{30}$.

In 1989, Bathon published a pioneering literature review with clinical and histopathologic features $^{31}$. The majority of these patients died (16 out of 19). Since then, RM has been labeled in the literature as a disease with a poor prognosis. However, according to case reports in the last decade $^{1-27}$ and recent case based reviews ${ }^{30,32}$ the majority of the patients experience full recovery or have only mild disability, and few cases have poor outcomes. RM onset can be months before the diagnosis of RA, as a presentation of RA, or in patients with long-standing disease (active or well-controlled disease). No sex predilection is observed, and the age at RM presentation is often in the sixties. Signs of synovitis and fever are uncommon. RF and anti-CCP levels are reported to be high in almost half of the patients. In the MRI, the involvement is commonly focal (more common in the frontal and parietal lobes), mainly with a mixed pachy-leptomeningeal or meningeal-parenchymal pattern. Most of the patients have a high CSF white cell count and half of the patients have high levels of protein in the CSF. Methylprednisolone is the most used treatment, with or without an additional immunotherapy, such as cyclophosphamide.

Characteristic histopathologic findings of RM include pachymeningitis or leptomeningitis, rheumatoid nodules and vasculitis ${ }^{31}$. The meningeal inflammatory infiltrate consists primarily of mononuclear cells, the rheumatoid nodules are histologically identical to subcutaneous rheumatoid nodules, and the vasculitis affects the smaller parenchymal and meningeal arteries ${ }^{12}$. However, these pathological features of RM are not specific and can also be present in tuberculous meningitis and other granulomatous diseases. Rheumatoid meningitis often presents with stroke-like episo$\mathrm{des}^{4-10}$. In these two cases, brain computed tomography (CT) angiography did not show signs of medium and large vessel vasculitis, thus vasculitis of smaller parenchymal arteries might be the cause of small size infarcts ${ }^{12}$. Crucial clues for the diagnosis of stroke-like attacks secondary to RM are the presence of concomitant headache or constitutional symptoms in patients with long-standing RA with either poorly ${ }^{6}$ or well controlled disease $e^{4,28}$ but also in patients with no history of RA ${ }^{29}$.

In conclusion, we suggest that in patients with RA, the possibility of RM should be considered in the differential diagnosis of neurological manifestations when the following features are present: A: a mixed MRI pattern with pachy-leptomeningeal or meningeal-parenchymal involvement; B: unaffected basal cisterns (unlike tuberculosis); C: ruled out infectious meningoencephalitis; $\mathrm{D}$ : ruled out other noninfectious causes of leptomeningeal involvement, such as carcinomatous meningitis or sarcoidosis; E: in the appropriate clinical setting normal CSF findings do not exclude meningitis $^{32,33}$ F: ruled out RM associated with TNF- $\alpha$ inhibitors including etanercept or infliximab ${ }^{28,34}$ and, G: rapid response to treatment with methylprednisolone.

\section{References}

1. Lu L, Chwalisz B, Pfannl R, Narayanaswami P. Rheumatoid meningitis: a rare complication of rheumatoid arthritis. BMJ Case Rep. 2015; 2015.

2. Yagita K, Shinde A, Suenaga T. Rheumatoid meningitis can present MRI findings that mimic chronic subdural haematoma. BMJ Case Rep. 2019; 12 (8).

3. Servioli MJ, Chugh C, Lee JM, Biller J. Rheumatoid meningitis. Front Neurol. 2011; 2: 84.

4. Akamatsu M, Maki F, Akiyama H, Hara D, Hoshino M, Hasegawa Y. Rheumatoid meningitis presenting with a stroke-like attack treated with recombinant tissue plasminogen activator: a case presentation. BMC Neurol. 2018 Sep; 18 (1): 139.

5. Oono M, Fujita Y, Uchida N, Kawai U, Fujita-Nakata M, Nakanishi M, et al. Rheumatoid meningitis developed in patient with stable rheumatoid arthritis and myasthenia 
gravis-detailed analysis of intracranial inflammation using flow cytometry. J Neuroinflammation. 2018; 15 (1): 151 .

6. Roy B, Uphoff DF, Silverman IE. Rheumatoid Meningitis Presenting With Multiple Strokelike Episodes. JAMA Neurol. 2015; 72 (9): 1073-6.

7. Bourgeois P, Rivest J, Bocti C. Rheumatoid meningitis presenting with stroke-like episodes. Neurology. 2014 Apr; 82 (17): 1564-5.

8. Choi S-J, Ho Park Y, Kim JA, Han JH, Choe G, Kim S. Pearls \& Oy-sters: Asymmetric meningeal involvement is a common feature of rheumatoid meningitis. Neurology. 2017; 88 (12): e108-10.

9. Matsushima M, Yaguchi H, Niino M, Akimoto-Tsuji S, Yabe I, Onishi K, et al. MRI and pathological findings of rheumatoid meningitis. J Clin Neurosci Off J Neurosurg Soc Australas. 2010; 17 (1): 129-32.

10. Schuster S, Braass H, Iking-Konert C, Schnoor U, Matschke J, Gerloff C, et al. Rheumatoid meningitis: A rare cause of aseptic meningitis with frequently stroke-like episodes. Neurol Clin Pract. 2018; 8 (5): 451-5.

11. Cianfoni A, Falcone C, Faustini F, Lauriola L, Imbesi S, Della Marca G, et al. Rheumatoid leptomeningitis: magnetic resonance imaging and pathologic findings--a case report. J Neuroimaging. 2010; 20 (2): 192-4.

12. Magaki S, Chang E, Hammond RR, Yang I, Mackenzie IRA, Chou BT, et al. Two cases of rheumatoid meningitis. Neuropathology. 2016;

13. Finkelshtein V, Lampl Y, Lorberboym M, Kanner A, Ben-Ami Raichman D, Dabby R, et al. Self-limited Rheumatoid Meningitis as a Presenting Symptom of Rheumatoid Arthritis. Isr Med Assoc J. 2018; 20 (4): 262-4.

14. Hasiloglu ZI, Asik M, Erer B, Dikici AS, Altintas A, Albayram S. Magnetic resonance imaging of rheumatoid meningitis: a case report and literature review. Rheumatol Int. 2012; 32 (11): 3679-81.

15. Lubomski M, Sy J, Buckland M, Lee AS, Richards B, Thompson E, et al. Rheumatoid leptomeningitis presenting with an acute neuropsychiatric disorder. Pract Neurol. 2019; 19 (1): 68-71.

16. Yaguchi M, Yaguchi H. Unilateral supratentorial lesion due to rheumatoid meningitis on MRI. Intern Med. 2008; 47 (21): 1947-8.

17. Koide R, Isoo A, Ishii K, Uruha A, Bandoh M. Rheumatoid leptomeningitis: rare complication of rheumatoid arthritis. Clin Rheumatol. 2009; 28 (9): 1117-9.

18. Alexander SK, Di Cicco M, Pohl U, Cifelli A. Rheumatoid disease: an unusual cause of relapsing meningoencephalitis. BMJ Case Rep. 2018; 2018.

19. Grose D, Linger M, Tinni S, Sahathevan R. Rheumatoid meningitis: a rare cause of unilateral pachymeningitis. BMJ Case Rep. 2019; 12 (4).

20. Schmid L, Muller M, Treumann T, Arnold W, Moller $\mathrm{B}$, Aeberli D, et al. Induction of complete and sustained remission of rheumatoid pachymeningitis by rituximab. Arthritis Rheum. 2009 Jun; 60 (6): 1632-4.

21. Kim HY, Park JH, Oh HE, Han HJ, Shin D-I, Kim $\mathrm{MH}$. A case of rheumatoid meningitis: pathologic and magnetic resonance imaging findings. Neurol Sci Off J Ital Neurol Soc Ital Soc Clin Neurophysiol. 2011; 32 (6): 1191-4.

22. Padjen I, Mayer M, Habek M, Kolenc D, Dotlic S. Redefining a diagnosis: from meningeal plasma cell granuloma to rheumatoid meningitis. Report of a patient follow-up. Neurol Sci 2015; 36 (6): 1047-8.

23. Krysl D, Zamecnik J, Senolt L, Marusic P. Chronic repetitive nonprogressive epilepsia partialis continua due to rheumatoid meningitis. Seizure. 2013; 22 (1): 80-2.

24. Ikeda K, Takazawa T, Ito H, Ishikawa Y, Miura K, Yoshii Y, et al. Rheumatoid leptomeningitis: radiological alteration of cerebral hypoperfusion and subarachnoid lesions. Intern Med. 2010; 49 (17): 1911-6.

25. Hayashi Y, Namekawa M, Ohtani K, Watanabe E, Nakano I. Parkinsonism as an initial manifestation of rheumatoid meningitis. Neurol Sci 2014; 35 (7): 1139-41.

26. Pellerin D, Wodkowski M, Guiot M-C, AlDhukair $\mathrm{H}$, Blotsky A, Karamchandani J, et al. Rheumatoid Meningitis Presenting With Acute Parkinsonism and Protracted Non-convulsive Seizures: An Unusual Case Presentation and Review of Treatment Strategies. Front Neurol 2019; 10: 163.

27. Kolenc D, Dotlic S, Adamec I, Zadro I, Stambuk C, Ozretic D, et al. Isolated plasma cell granuloma of the meninges. Neurol Sci 2013; 34 (12): 2245-7.

28. Tsuzaki K, Nakamura T, Okumura H, Tachibana N, Hamano T. Rheumatoid Meningitis Occurring during Etanercept Treatment. Case Rep Neurol Med 2017; 7638539.

29. Roques M, Tanchoux F, Calviere L, Cuinat L, Lubrano V, Uro-Coste E, et al. MRI with DWI helps in depicting rheumatoid meningitis. J Neuroradiol 2014; 41 (4): 275-7.

30. Qin Z, Kim J, Valencia D, Hamoodi L, Neltner J, Sizemore $T$, et al. Rheumatoid meningitis: A case report and review of the literature. Neurol Clin Pract 2020; 10 (1): 73-83.

31. Bathon JM, Moreland LW, DiBartolomeo AG. Inflammatory central nervous system involvement in rheumatoid arthritis. Semin Arthritis Rheum 1989; 18 (4): 258-66.

32. Rodriguez Alvarez M, Rodríguez Valencia LM, Seidman 
R, Acharya A, Espina N, Ravindran N, et al. Rheumatoid meningitis and infection in absence of rheumatoid arthritis history: review of 31 cases. Clin Rheumatol 2020; 39 (12): 3833-45.

33. Dawood N, Desjobert E, Lumley J, Webster D, Jacobs M.
Confirmed viral meningitis with normal CSF findings. BMJ Case Rep. 2014; bcr2014203733.

34. Seago S, Stroberg E, Metting A. Rheumatoid meningitis associated with infliximab. Proc (Bayl Univ Med Cent) 2016; 29 (2): 204-6. 